mothers with anti-HBe the incidence of perinatal transmission of hepatitis $\mathrm{B}$ virus is much lower, estimates varying between $10 \%$ and $20 \%{ }^{4-6}$ The prevalence of $\mathrm{HBsAg}$, anti-HBe positive women, however, is about five times that of $\mathrm{HBsAg}, \mathrm{HBeAg}$ positive mothers. ${ }^{56}$ Because of the relatively high proportion of $\mathrm{HBsAg}$, anti-HBe positive mothers the number of children infected with hepatitis B virus from this source should not be neglected. It is, however, important that according to several reports infants of anti-HBe positive mothers develop chronic HBs antigenaemia only in a small minority of cases, ${ }^{6}{ }^{7}$ but the manifestations of the disease vary from usually asymptomatic to fulminant hepatitis. ${ }^{78}$ In view of the (albeit infrequent) occurrence of severe disease in children of anti-HBe positive mothers we, like others, ${ }^{9} 10$ suggest that all neonates of $\mathrm{HBsAg}$ positive mothers should be candidates for immunisation against hepatitis B infection. Current costs of active immunisation, however, may prevent general acceptance of this until a cheaper vaccine becomes available.

We thank Mrs H Ribbers, M Bakker, A Vollaard, and M Reynen for excellent administrative help.

The study was supported by a grant from the Praeventiefonds, the Netherlands. The advisory committee was composed of J Huisman, J W Stoop, H Bijkerk, and S Krugman.

ADDENDUM-A recent study has shown the efficacy of passiveactive immunisation in neonates of oriental $\mathrm{HBeAg}$ positive carrier mothers. ${ }^{11}$ The dose of HBIg (145 IU) was similar to that in our study (roughly $150 \mathrm{IU}$ ), but doses of vaccine were twice as high ( $20 \mu \mathrm{g}$ compared with $10 \mu \mathrm{g}$ in our study).

\section{References}

${ }^{1}$ Palmer Beasley R, Hwang LY, Stevens CE, et al. Efficacy of hepatitis B immune globulin for prevention of perinatal transmission of hepatitis $B$ virus carrier-state: final report of a randomized double-blind, placebocontrolled trial. Hepatology 1983;3:135-41.

${ }^{2}$ Barin F, Goudeau A, Denis F, et al. Immune response in neonates to hepatitis B vaccine. Lancet 1982 ; : 251-3.

${ }^{3}$ Francis DP, Hadler SC, Thompson SE, et al. The prevention of hepatitis B with vaccine. Ann Intern Med 1982;97:362-6.

${ }^{4}$ Reesink HW, Reerink-Brongers EE, Lafeber-Schut BJTh, KalshovenBenschop J, Brummelhuis HGJ. Prevention of chronic HBsAg carrier state in infants of HBsAg-positive mothers by hepatitis B immunoglobulin. Lancet 1979;ii:436-7.

${ }^{6}$ Y pma TjD, Kater L, Gerards LJ, Heiden Cvd, Heijtink RA, Haspels AA. Perinataal verworven virushepatitis B. Ned Tijdschr Geneeskd 1979; $123: 1820-8$.

${ }^{6}$ Rosendahl C, Kochem MM, Kretschemer R, Wegschneider K, Kaiser D. Avoidance of perinatal transmission of hepatitis $B$ virus: is passive immunization always necessary ? Lancet $1983 ;$; :1127-9.

${ }^{7}$ Shiraki K, Yoshihara N, Sakurai M, Eto T, Kawana T. Acute hepatitis B in infants born to carrier mothers with the antibody to hepatitis $\mathrm{Be}$ antigen. $\mathcal{F}$ Pediatr 1980;97:768-70.

${ }^{8}$ Naggan L, Gorodischer R, Bar-Shany S, Sarow B. Clinical hepatitis B in two infants born to asymptomatic HBsAg carrier mothers. Isr $\mathcal{f}$ Med Sci 1983;19:292-3.

${ }^{9}$ Sinatra FR, Shah P, Weissman JY, Thomas DW, Meritt RJ, Tong MJ. Perinatal transmitted acute icteric hepatitis in infants born to hepatitis $B$ surface antigen positive, and antihepatitis Be positive carrier mothers. Pediatrics 1982;70:557-9.

${ }^{10}$ Delaplane D, Shulman ST, Esteban JI, et al. Immunoprophylaxis for infants born to HBsAg-positive mothers. Lancet 1983;ii:170-1.

11 Palmer Beasley R, Hwang Lu-Yu, Chin-Yun Lee George, et al. Prevention of perinatally transmitted hepatitis $B$ virus infections with hepatitis B immune globulin and hepatitis B vaccine. Lancet 1983;ii: 1099-102.

(Accepted 18 October 1983)

\title{
Development of pituitary adenoma in women with hyperprolactinaemia: clinical, endocrine, and radiological characteristics
}

\author{
ANTONIO E PONTIROLI, LEOPOLDO FALSETTI
}

\begin{abstract}
Sixty eight women referred for treatment of hyperprolactinaemia entered a three year follow up study to determine the clinical and endocrine course of the disease and its association with microadenoma of the pituitary. Details recorded before treatment included medical history, gonadotrophin and ovarian hormonal concentrations, and release of prolactin in response to protirelin (thyrotrophin releasing hormone), benserazide, cimetidine, and nomifensine. Sellar tomography was then performed yearly for three years in all women, 54 of them also undergoing computed coronal and sagittal
\end{abstract}

Clinica Medica, Università di Milano, Istituto Scientifico Ospedale San Raffaele, Milan, Italy

ANTONIO E PONTIROLI, MD, established investigator

Clinica Ostetrica, Universitâ di Brescia, Spedali Civili, Brescia LEOPOLDO FALSETTI, MD, senior registrar

Correspondence to: Dr Antonio E Pontiroli, Ospedale San Raffaele, 20132 Milano, Italy. tomography. At baseline evaluation 27 women showed radiological evidence of pituitary adenoma; at the end of the follow up period the number had increased to 41 . Amenorrhoea, steady and raised serum prolactin concentrations, a low ratio of luteinising hormone to follicle stimulating hormone, a longer duration of disease, and low serum progesterone concentrations were more common in women with a final diagnosis of pituitary adenoma than in those whose sella remained normal. Tests for release of prolactin had yielded abnormal results from the outset in all 41 women with radiological evidence of pituitary adenoma and in about half of those whose sella had remained radiologically normal. Response to medical treatment (metergoline in 20 patients, bromocriptine in 21) was similar and showed no difference between patients with tumorous and non-tumorous hyperprolactinaemia.

These findings suggest that a large proportion of women with hyperprolactinaemia may harbour a prolactin secreting pituitary adenoma which becomes apparent over a relatively short period. Amenorrhoea and steady and raised serum prolactin concentrations are more common in these women. Tests for release of prolactin are of predictive value in identifying women who will develop a pituitary adenoma. 


\section{Introduction}

Hyperprolactinaemia induces amenorrhoea, galactorrhoea, and infertility and may be due to pituitary adenoma or be a functional (idiopathic) disorder. The natural history of hyperprolactinaemia is not known, ${ }^{1}$ and the rate of growth of microadenomas is a subject of controversy. ${ }^{2}{ }^{3}$ With large adenomas the diagnosis is easy, but this is not so with small prolactin secreting adenomas (microadenomas). Minor changes of the sella turcica detected by sellar tomography have been taken as evidence of microadenoma, ${ }^{4}$ but with both sellar tomography and computed tomography (CT) false negative and false positive results may occur. ${ }^{56}$ In addition, permanently raised serum prolactin concentrations ${ }^{7}$ and the absence of response of prolactin to provocative stimuli (protirelin; thyrotrophin releasing hormone), cimetidine, and benserazide $)^{8-10}$ and to inhibiting stimuli (nomifensine and levodopa-carbidopa) ${ }^{11}{ }^{12}$ have also reportedly been shown to characterise patients with prolactin secreting pituitary adenomas. The validity of such tests has been questioned, however, since an absent prolactin response may also be observed in patients with a normal radiological appearance of the sella. ${ }^{13}$

With the assumption that patients with hyperprolactinaemia might be harbouring a microadenoma which was still too small to be seen we decided to follow up hyperprolactinaemic women for up to three years and to correlate the final radiological diagnosis with baseline clinical and endocrine findings-namely, details of medical history, pituitary and ovarian hormonal release, and response of prolactin to various stimuli.

\section{Patients and methods}

During January 1978 to January 1980, 68 women with hyperprolactinaemia (at least two measurements $>20 \mu \mathrm{g} / \mathrm{l}$ on different days) and various reproductive disorders (amenorrhoea or anovulation with or without galactorrhoea, polycystic ovarian disease, infertility due to a short luteal phase) entered the study. After exclusion of other endocrine disorders known to induce secondary hyperprolactinaemia (acromegaly, Cushing's disease, Nelson's syndrome, primary hypothyroidism, Addison's disease, chronic renal failure) patients were categorised according to the duration of symptoms or ascertained clinical condition. Seven patients had received drugs known to induce hyperprolactinaemia-namely, oestrogens and metoclopramide-but were not excluded. Before beginning any medical treatment all patients underwent a baseline evaluation of serum prolactin concentrations (two or three samples over a three month period) and concentrations of $17 \beta$-oestradiol, progesterone, testosterone, follicle stimulating hormone (FSH), and luteinising hormone (LH). Sellar tomography was performed in all women and sagittal and coronal CT in $\mathbf{5 4}$ of them by means of a third generation IGE 8800 scanner (47 from the outset and seven from one year later). All women underwent a stimulatory test for prolactin release with benserazide ( $150 \mathrm{mg}$ by mouth). ${ }^{10} \mathrm{~A}$ test with protirelin (thyrotrophin releasing hormone; $200 \mu \mathrm{g}$ intravenously) was performed in 59 patients, ${ }^{8}$ with cimetidine ( $400 \mathrm{mg}$ intravenously) ${ }^{9} 1314$ in 37 women, and with nomifensine $(200 \mathrm{mg} \text { orally })^{11}$ in 28 patients.

In 41 women medical treatment was instituted with metergoline
(20 cases; $8-12 \mathrm{mg} /$ day) ${ }^{15}$ or bromocriptine ( 21 cases; $5-10 \mathrm{mg} /$ day), ${ }^{16}$ and after at least 90 days efficacy established as: no result; menses; ovulatory menses; pregnancy.

All patients were followed up for three years by means of sellar tomography or CT, or both, performed yearly. Results of sellar tomography were evaluated by two independent neuroradiologists using the criteria of Vezina and Sutton. ${ }^{+}$Close attention was paid to changes in the sella on repeated examinations (performed under standardised conditions and with the same instrument) rather than to abnormalities seen at a single examination, which might have been due to anatomical variation. With CT a microadenoma was defined as the presence of a hypodense round or oval area within the hypophysis after intravenous injection of contrast media: additional criteria were the displacement of the pituitary stalk or erosions of the bony structures.

In the benserazide, protirelin, and cimetidine tests a normal prolactin response was defined as doubling of baseline prolactin values $^{8}{ }^{10}$; in the nomifensine test a normal response was defined as a mean prolactin concentration at 120,180 , and 240 minutes, at least $33 \%$ lower than baseline. ${ }^{11}$ Serum prolactin, FSH, LH, progesterone, $17 \beta$-oestradiol, and testosterone concentrations were determined by specific radioimmunoassays; in our hands the interassay coefficients of variation vary from $5.8 \%$ for progesterone to $7.5 \%$ for testosterone, and the intra-assay coefficients of variation vary from $4.0 \%$ for prolactin to $6.6 \%$ for progesterone.

Statistical analysis was by Student's $t$ test for unpaired data and the $\chi^{2}$ test.

\section{Results}

At baseline evaluation 41 patients were found to have a normal sella, as assessed by sellar tomography or CT, and 27 patients showed evidence of pituitary adenoma. Table I gives the details of the two groups. Prolactin concentrations were found to be steady in each group, but the actual mean values differed significantly $(p<0 \cdot 02)$. Also the mean $\mathrm{LH} / \mathrm{FSH}$ ratio and serum progesterone concentration were lower in patients with radiological evidence of pituitary tumour, whereas no significant differences were found in the age of the patients, prevalence of amenorrhoea, duration of the clinical condition, or serum testosterone or $17 \beta$-oestradiol concentration. Testing for release of prolactin showed no modification with any agent in patients with evidence of adenoma; however, a preponderance of absent prolactin responses to each test was also found in most patients with a normal radiological appearance of the sella turcica.

At the end of the follow up period there was an impressive increase in the number of patients with radiological evidence of pituitary adenoma as detected by sellar tomography or CT, the final number having reached 41 cases. In two cases in which appearances on sellar tomography had suggested a diagnosis of adenoma CT allowed a final diagnosis of empty sella. Of 15 women with a final diagnosis of adenoma and who had had a normal sella at the outset, 11 had been evaluated by both sellar tomography and CT, six of them simultaneously. In three patients in the latter group CT detected a pituitary adenoma earlier than did sellar tomography, and in the others detection occurred at the same time. Surgical exploration was attempted in eight patients, and in every one a pituitary adenoma was confirmed. Of these eight patients, six had had radiological evidence of adenoma from the outset.

Table II gives the details of the patients at the end of the follow up period. The prevalence of amenorrhoea, duration of the disease,

TABLE I-Classification of hyperprolactinaemic women according to radiological appearances at baseline evaluation. (Mean values expressed with SE in parentheses)

\begin{tabular}{|c|c|c|c|c|c|c|c|c|c|c|c|c|c|}
\hline \multirow{3}{*}{$\begin{array}{l}\text { Radiological appearance } \\
\text { (sellar and computed tomography) }\end{array}$} & \multirow{3}{*}{$\begin{array}{l}\text { No with } \\
\text { amenorrhoea }\end{array}$} & \multirow{3}{*}{$\begin{array}{c}\text { Mean } \\
\text { duration } \\
\text { of history } \\
\text { (years) }\end{array}$} & \multirow{3}{*}{ 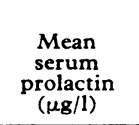 } & \multirow{3}{*}{ 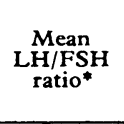 } & \multirow{3}{*}{$\begin{array}{c}\text { Mean } \\
\text { serum } \\
\text { progesteronet } \\
(\text { (nmol/l) }\end{array}$} & \multicolumn{8}{|c|}{ No with or without prolactin response to: } \\
\hline & & & & & & \multicolumn{2}{|c|}{ Benserazide } & \multicolumn{2}{|c|}{ Protirelin } & \multicolumn{2}{|c|}{ Nomifensine } & \multicolumn{2}{|c|}{ Cimetidine } \\
\hline & & & & & & No & Yes & No & Yes & No & Yes & No & Yes \\
\hline Pituitary tumour $(n=27)$ & 19 & $(1 \cdot 3)$ & $\left\{\begin{array}{l}122(17) \\
127(24)\end{array}\right\}$ & $0.7(0 \cdot 1)$ & $0.61(0.09)$ & 27 & 0 & 27 & 0 & 15 & 0 & 15 & $\mathbf{0}$ \\
\hline Normal sella $(n=41)$ & 20 & $5 \cdot 2(0.8)$ & $\left.\begin{array}{ll}77 & (9) \\
64 & (9)\end{array}\right\}$ & $1 \cdot 2(0 \cdot 1)$ & $2.59(0.73)$ & 26 & 15 & 23 & 9 & 10 & 3 & 15 & 5 \\
\hline p Value & NS & NS & $<0.02$ & $<0.02$ & 0.01 & & & & & & & & \\
\hline
\end{tabular}

NS = Not significant.

-Three patients in group with pituitary tumour and 16 in group with normal sella had LH/FSH ratio greater than $1.0\left(\chi^{2}=4.99 ; p<0.05\right)$.

tOvulatory concentrations of serum progesterone $(>12.7 \mathrm{nmol} / 1 ;>4000 \mathrm{pg} / \mathrm{ml})$ detected in four patients in group with normal sella and in no patient in group with pituitary umour $\left(x^{2}=\right.$ NS).

Conversion: SI to traditional units-Progesterone: $1 \mathrm{nmol} / 1 \approx 315 \mathrm{pg} / \mathrm{ml}$ 
TABLE II-Classification of hyperprolactinaemic women according to radiological appearances at end of follow up period. (Mean values expressed with SE in parentheses)

\begin{tabular}{|c|c|c|c|c|c|c|c|c|c|c|c|c|c|}
\hline \multirow{3}{*}{$\begin{array}{l}\text { Radiological appearance } \\
\text { (sellar and computed tomography) }\end{array}$} & \multirow{3}{*}{$\begin{array}{l}\text { No with } \\
\text { amenorrhoea }\end{array}$} & \multirow{3}{*}{$\begin{array}{c}\text { Mean } \\
\text { duration } \\
\text { of history } \\
\text { (years) }\end{array}$} & \multirow{3}{*}{$\begin{array}{c}\text { Mean } \\
\text { serum } \\
\text { prolactin } \\
(\mu \mathrm{g} / 1)\end{array}$} & \multirow{3}{*}{ 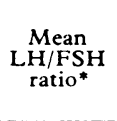 } & \multirow{3}{*}{$\begin{array}{c}\text { Mean } \\
\text { serum } \\
\text { progesterone† } \\
(\mathrm{nmol} / \mathrm{l})\end{array}$} & \multicolumn{8}{|c|}{ No with or without prolactin response to: } \\
\hline & & & & & & \multicolumn{2}{|c|}{ Benserazide } & \multicolumn{2}{|c|}{ Protirelin } & \multicolumn{2}{|c|}{ Nomifensine } & \multicolumn{2}{|c|}{ Cimetidine } \\
\hline & & & & & & No & Yes & No & Yes & No & Yes & No & Yes \\
\hline Pituitary tumour $(n=41)$ & 29 & $7 \cdot 9(0.9)$ & \multirow{2}{*}{$\begin{array}{r}113(12) \\
116(15) \\
67(7) \\
42(7)\end{array}$} & $0.8(0 \cdot 1)$ & $1.00(0.34)$ & 41 & 0 & 41 & 0 & 22 & 0 & 25 & 0 \\
\hline Normal sella $(n=25)$ & 10 & $4.4(0.9)$ & & $1 \cdot 4(0 \cdot 2)$ & $3 \cdot 46(1 \cdot 14)$ & $10 \pm$ & $15 \ddagger$ & 9 & 9 & 3 & 3 & 5 & 5 \\
\hline p Value & 0.05 & 0.02 & 0.001 & $<02$ & $<0.05$ & & & & & & & & \\
\hline
\end{tabular}

* Seven patients with pituitary tumour and 12 with normal sella had LH/FSH ratio greater than $1.0\left(\chi^{2}=7 \cdot 24 ; \mathrm{p}-0.02\right)$.

+Ovulatory concentrations of serum progesterone detected in four patients with normal sella and in no patient with pituitary tumour $\left(\chi^{2}=6.98\right.$; $\left.p<0.05\right)$.

tAnalysis of patients with normal sella subdivided according to responsiveness to benserazide: Non-responsive $(\mathrm{n}=10)-$ No with amenorrhoea, 8 ; mean serum prolactin, 57 (SE 7) and $66(12) \mu \mathrm{g} / \mathrm{l}$. Responsive $(\mathrm{n}=15)$ - No with amenorhoea, 2; mean serum prolactin 63 (SE 11$)$ and 25 (4) $\mu \mathrm{g} / 1$. Significance of difference $\mathrm{p}<0.005$ ( $\chi^{2}$ test).

Conversion: SI to traditional units-Progesterone: $1 \mathrm{nmol} / \mathrm{l} \approx 315 \mathrm{pg} / \mathrm{ml}$

serum prolactin and progesterone concentrations, and $\mathrm{LH} / \mathrm{FSH}$ ratio were all significantly different between the patients with a radiologically normal sella and those with tumour; serum testosterone and $17 \beta$-oestradiol concentrations, however, were closely similar. On subdividing patients with a normal appearance of the pituitary fossa according to the results of testing for prolactin release (table II) the only difference noted was a spontaneous decline in prolactin concentrations in those who had given a normal response. Patients with iatrogenic hyperprolactinaemia were almost all confined to this subgroup $(n=6)$. Tests with the four agents invariably yielded concordant results in patients who from the outset or from some time during follow up had shown radiological evidence of pituitary adenoma; discrepancies were observed in only six out of 19 patients whose sella remained radiologically normal and who were tested with more than one agent.

Effects of treatment-A total of 41 patients were treated with either metergoline or bromocriptine. Of these, four achieved no benefit, while menses were induced in 13 and ovulatory menses in $11 ; 12$ patients became pregnant. Therapeutic outcome was independent of the final radiological diagnosis, basal prolactin concentration, and drug used. Pregnancy occurred in both cases of empty sella. Though beyond the original aims of the study, the possible effect of medical treatment on the development of a pituitary adenoma was evaluated retrospectively. Of 15 patients whose sella remained normal radiologically, 11 had been treated with either metergoline or bromocriptine; of 15 patients whose sella changed in appearance, $13 \mathrm{had}$ been treated with either drug (difference not significant).

\section{Discussion}

In patients with hyperprolactinaemia one of the greatest difficulties is in differentiating between functional hyperprolactinaemia and pituitary adenoma. Attempts to characterise the disease have been based on serial determinations of serum prolactin concentrations and the response of prolactin to stimulating and inhibiting agents, but the validity of these approaches has been questioned. ${ }^{2-13}$ Radiological evaluation of the sella turcica has been greatly improved by high resolution computed tomography, which has replaced traditional invasive diagnostic procedures such as pneumoencephalography and cerebral angiography. A firm criterion for radiological diagnosis of pituitary adenomas, however, is not available. ${ }^{6}$

Unfortunately, the natural history of hyperprolactinaemia is not known. ${ }^{1}$ Functional hyperprolactinaemia and pituitary adenoma may represent two different entities or be consecutive stages of the same disorder. ${ }^{13}$ Anecdotal evidence indicates that some cases of functional hyperprolactinaemia will be followed by detection of a pituitary prolactin secreting pituitary adenoma. ${ }^{2} 3131718$ The need for early diagnosis of a prolactin secreting adenoma lies in the fact that cure is obtained only by operation at an early stage, ${ }^{19}$ although even then recurrence of hyperprolactinaemia is common. ${ }^{20}$ On the other hand, the surgical approach is often refused by patients unless serious local disturbances are present-for example, severe headache or visual field defects.

In our study 68 women with hyperprolactinaemia were followed up for three years; the number with radiological evidence of pituitary adenoma increased from $27(39 \cdot 7 \%)$ to $41(60 \cdot 3 \%)$. That so many cases were detected was probably due to the extensive use of combined sellar tomography and CT scans; some patients were initially examined by sellar tomography and later by CT scan, but in most instances changes were observed with repeated use of the same technique.

At the end of the follow up period there were clear differences between patients with and without radiological evidence of tumour which had not been present at the baseline evaluation. Amenorrhoea, a longer duration of disease, steady and raised prolactin concentrations, a low $\mathrm{LH} / \mathrm{FSH}$ ratio, and low serum progesterone concentrations had been more common in patients with radiological evidence of adenoma than in patients whose sella remained normal. In addition, in about half of the patients with a normal sella prolactin had shown no response to the various tests. A significant spontaneous decrease of basal prolactin concentrations was observed only in patients with a normal prolactin response to the tests (table II). Interestingly six of the seven patients with iatrogenic hyperprolactinaemia were in the latter group.

In patients with a persistently normal sella and no prolactin response to the various tests the non-responsiveness might be idiopathic. We, however, could not find a normal subjectmale or female-who did not respond to each of the tests, which suggests another interpretation-that these patients harbour an extremely slow growing pituitary (micro)adenoma. Cases of pituitary adenomas enlarging over eight years have been reported. ${ }^{21}$ Our data therefore indicate that an impaired prolactin response to the tests may precede radiological evidence of pituitary adenoma by one to three years. The tests used in this study assess dopaminergic ${ }^{10} 11$ and histaminergic control ${ }^{914}$ of prolactin secretion, while protirelin acts by a different mechanism. ${ }^{10}$ That the result of each of these tests was impaired indicates that the adenoma physically interrupts the connections between the hypothalamus and the pituitary. An augmented dopaminergic tone in the tuberoinfundibular area has been found in animals with hyperprolactinaemia ${ }^{22}$; hence the well known inhibitory effect of dopamine and of dopaminergic drugs on $\mathrm{LH}$ release $^{23}$ might explain the lower concentrations of $\mathrm{LH}$ and consequently the lower $\mathrm{LH} / \mathrm{FSH}$ ratio in patients with adenoma. Medical treatment was given to 41 patients; pregnancy and ovulation wer* induced in similar proportions of patients with a normal sella or pituitary adenoma, showing that the response was not influenced by the anatomical condition or baseline prolactin concentration. Our data also indicate that prolactin lowering agents at doses commonly used $^{1516}$ do not prevent a pituitary adenoma, ${ }^{16}$ especially if such doses fail to control hyperprolactinaemia.

In conclusion, patients with hyperprolactinaemia are likely to harbour a pituitary (micro)adenoma; the likelihood increases with the duration of the disease and in the presence of amenorrhoea, steady and raised serum prolactin concentrations, and a low $(<1.0) \mathrm{LH} / \mathrm{FSH}$ ratio. Stimulatory and inhibiting tests for prolactin release seem to be of adequate predictive value in identifying patients who will develop a pituitary adenoma but do not predict the response to medical treatment. 


\section{References}

1 Anonymous. Hyperprolactinaemia: pituitary tumour or not? Lancet $1980 ; \mathrm{i}: 517-9$.

${ }^{2}$ Gomez F, Reyes F, Faiman C. Nonpuerperal galactorrhea and hyperprolactinemia. Am F Med 1977;62:648-54.

${ }^{3}$ Rjosk HK, Fahlbusch R, vonWerder K. Spontaneous development of hyperprolactinemia. Acta Endocrinol (Copenh) 1982;100:333-6.

4 Vezina JL, Sutton TJ. Prolactin-secreting pituitary microadenoma; roentgenologic diagnosis. $A \mathcal{F} R$ 1974;120:46-54.

${ }^{5}$ Swanson HA, du Boulay G. Borderline variants of the normal pituitary fossa. Br F Radiol 1975;48:366-9.

6 Burrow GN, Wortzman G, Rewcastle NB, Holgate RC, Kovacs K. Microadenomas of the pituitary and abnormal sellar tomograms in an unselected autopsy series. $N$ Engl f Med 1981 ;304:156-8.

${ }^{7}$ Jeske W. The effect of metoclopramide, TRH and L-dopa on prolactin secretion in pituitary adenoma and in functional galactorrhea syndrome. Acta Endocrinol (Copenh) 1979;91:385-96.

${ }^{8}$ MacGregor C, Maldonado D, Canales ES, Soria J, Zarate A. Prolactin responsiveness to TRH in amenorrheic women with and without galactorrhea. Acta Obstet Gynecol Scand 1977;56:333-6.

${ }^{9}$ Gonzalez-Villapando G, Szabo M, Frohman LA. Central nervous system mediated stimulation of prolactin secretion by cimetidine, a histamine $\mathrm{H}_{2}$ receptor antagonist: impaired responsiveness in patients with prolactin-secreting tumors and idiopathic hyperprolactinemia. $\mathcal{F}$ Clin Endocrinol Metab 1980;51:1417-24.

10 Pontiroli AE, Falsetti L, Voltolini AM, et al. Benserazide, a stimulator of prolactin release: a new test in the diagnosis of pituitary prolactin secreting tumors. Acta Endocrinol (Copenh) 1981 ; 78:326-32.

$"$ Muller EE, Genazzani AR, Murru S. Nomifensine: diagnostic test in hyperprolactinemic states. F Clin Endocrinol Metab 1978;47:1352-7.

12 Fine SA, Frohman LA. Loss of central nervous system component of dopaminergic inhibition of prolactin secretion in patients with prolactinsecreting pituitary tumors. F Clin Invest 1978;61:973-80.

${ }^{13}$ Peters JR, Foord SM, Dieguez C, Rodriguez-Arnao MD, Hall R, Scanlon MF. Microprolactinoma and functional hyperprolactinemia: two clinical entities or two phases of the same disease ? In: Molinatti GM, ed. A clinical problem: microprolactinoma. Amsterdam: Excerpta Medica, 1982:21-34. (ICS No 584.)

14 Pontiroli AE, De Castro e Silva E, Mazzoleni F, et al. The effect of histamine and $\mathrm{H}_{1}$ and $\mathrm{H}_{2}$ receptors on prolactin and luteinizing hormone release in humans; sex difference and the role of stress. $\mathcal{F}$ Clin Endocrinol Metab $1981 ; 52: 924-8$.

${ }^{15}$ Ferrari C, Reschini E, Peracchi M, Crosignani PG. Endocrine profile and therapeutic employment of a new prolactin-lowering drug, metergoline. Gynecol Obstet Invest 1980;11:1-11.

${ }^{16}$ Lancranjan I. Increasing use of dopamine agonists as the first choice therapy of prolactin-secreting adenomas. In: Molinatti GM, ed. $A$ clinical problem: microprolactinoma. Amsterdam: Excerpta Medica, 1982:103-13. (ICS No 584.)

17 Wiebe RH, Hammond CB, Borchert LG. Diagnosis of prolactin-secreting pituitary microadenoma. Am f Obstet Gynecol 1976;126:993-6.

18 Pontiroli AE, Loda G, Roggia A, Scagliola P, Falsetti L. Benserazide and nomifensine in the diagnosis of prolactin-secreting pituitary adenomas. Acta Endocrinol (Copenh) 1982;101:171-9.

${ }^{19}$ Keye WR, Chang RJ, Jaffe RB. Hyperprolactinemic amenorrhea. $N$ Engl f Med 1977;297:396-401.

${ }^{20}$ Serri O, Rasio E, Beauregard H, Hardy J, Somma M. Recurrence of hyperprolactinemia after selective transphenoidal adenomectomy in women with prolactinoma. N Engl f Med 1983;309:280-3.

21 Tucker HSG, Grubb SR, Wigand JP, et al. Galactorrhea-amenorrhea syndrome; follow-up of forty five patients after pituitary tumor removal. Ann Intern Med 1981;94:302-7.

${ }^{22}$ Hokfelt T, Fuxe K. Effects of prolactin and ergot alkaloids on the tuberoinfundibular dopamine neurons. Neuroendocrinology 1972;9:100-72.

${ }^{23}$ Pontiroli AE, Pellicciotta G, De Castro e Silva E, et al. Interaction of dopaminergic and antiserotoninergic drugs in the control of prolactin and LH release in normal women. Acta Endocrinol (Copenh) 1980;93: $271-6$

\title{
Methimazole and generation of oxygen radicals by monocytes: potential role in immunosuppression
}

\author{
A P WEETMAN, MARY E HOLT, A K CAMPBELL, R HALL, A M MCGREGOr.
}

\begin{abstract}
A study was conducted investigating the possibility that the immunosuppressive action of methimazole (the active metabolite of the antithyroid drug carbimazole) might be due to an effect on the production of oxygen radicals by monocytes. Techniques comprised measurement of luminol dependent chemoluminescence in monocytes and a spectrophotometric assay for production of hydrogen peroxide.

The results showed definite inhibition of formation of oxygen radicals by resting and stimulated monocytes, which may explain the immunosuppressive action of the drug in Graves' disease. The findings also suggest that the formation of oxygen radicals and the initiation of the immune response may be closely related.
\end{abstract}

Welsh National School of Medicine, Heath Park, Cardiff CF4 4XN A P WEETMAN, MD, MRCP, lecturer, department of medicine MARY E HOLT, MRCP, senior registrar in rheumatology A K CAMPBELL, PHD, reader in medical biochemistry

R HALL, MD, FRCP, professor of medicine

A M MCGREGOR, MD, MRCP, Wellcome senior fellow, honorary consultant physician

Correspondence to: Dr A P Weetman.

\section{Introduction}

Phagocytic and chemotactic stimuli such as opsonised zymosan and phorbol myristate acetate provoke a respiratory burst in macrophages and polymorphonuclear leucocytes characterised by an increase in oxygen consumption, activation of the hexose monophosphate shunt, and generation of oxygen radicals. Formation of superoxide anion $\left(\mathrm{O}_{2}-\right)$, the first of these radicals, is apparently catalysed by a membrane bound reduced form of nicotinamide adenine dinucleotide phosphate oxidase and a unique $b$ cytochrome. ${ }^{2}$ This is followed by dismutation of $\mathrm{O}_{2}$ to hydrogen peroxide $\left(\mathrm{H}_{2} \mathrm{O}_{2}\right)$ and various further reactions which yield the highly reactive oxygen metabolites hydroxyl radical $(\mathrm{OH} \cdot)$, singlet oxygen $\left({ }^{1} \mathrm{O}_{2}\right)$, and hypochlorite anion $\left(\mathrm{OCl}^{-}\right){ }^{3}$ Although the role of these active oxygen species in microbial killing and cytotoxicity is established, ${ }^{3}{ }^{4}$ their possible effects on other immune responses such as antibody production have received much less attention.

We recently showed that methimazole, the active metabolite of the antithyroid drug carbimazole, is an immunosuppressant which inhibits antibody production by an action on antigen presenting monocytes. ${ }^{5} \mathrm{We}$ have now investigated the possibility that this might be due to an effect on the production of oxygen radicals by these cells, since intracellular peroxidase is linked to the uptake of methimazole by cells ${ }^{6}$ and inhibition of peroxidase within the thyroid follicular cell has been proposed as the primary mechanism of the drug's antithyroid activity. ${ }^{7}$ In this 